\title{
Assessing patterns of fish zonation in temperate mangroves, with emphasis on evaluating sampling artefacts
}

\author{
Jeremy S. Hindell ${ }^{1,2, *}$, Gregory P. Jenkins ${ }^{1,2}$ \\ ${ }^{1}$ Marine and Freshwater Systems, Primary Industries Research Victoria, PO Box 114, Queenscliff 3225, Australia \\ ${ }^{2}$ Department of Zoology, University of Melbourne, Parkville 3010, Australia
}

\begin{abstract}
Mangroves and mudflats are a conspicuous element of temperate estuaries in southeastern Australia, but our understanding of their use by fish is poor. A combination of experimental and survey methods were used to investigate (1) the utility of pop nets in sampling fishes and (2) patterns in fish assemblages among mangrove zones (forest, edge, mudflat) in 2 large embayments between October 2003 and January 2004. In the experimental assessment of pop net artefacts, there were no statistically significant differences ( $p$ > 0.05) in assemblage structure, species richness (number of species) or abundances of fish among net disturbance treatments regardless of structure (seagrass or unvegetated sand). These results were not simply due to type II errors. The statistical power to observe an effect of net disturbance on fish abundances and species richness generally exceeded $80 \%$. In the pop net survey of fish using mangrove zones, only 15 species of fish (9 families) were caught, but assemblages varied strongly among zones. Small $(<30 \mathrm{~mm})$ benthic gobiids, such as Pseudogobius olorum Sauvage 1880 and Mugilogobius paludis Whitley 1930, and juveniles of the atherinid Atherinasoma microstoma Gunther 1861 dominated catches in the forest. The sillaginid Sillaginodes punctata Cuvier 1829, the tetraodontid Tetractenos glaber Freminville 1813 and a further 2 species of gobiid, Arenigobius frenatus Gunther 1861 and Favonigobius lateralis Macleay 1881, dominated catches along the edge and over the mudflat, but these species were more abundant along the edge. Fish densities were significantly lower $(\mathrm{p}<0.05)$ in the mudflats $\left(0.37 \pm 0.05\right.$ fish $\left.\mathrm{m}^{-2}\right)$ than in the forest $(1.98 \pm 0.36)$ or at the edge $(1.42 \pm 0.43)$; species richness was greater along mangrove edges $\left(0.25 \pm 0.19\right.$ species $\left.\mathrm{m}^{-2}\right)$ than in the forest $(0.17 \pm 0.06)$ and in the mudflats $(0.12 \pm 0.02)$; biomass was greater (but not significantly) at the edge $\left(4.64 \pm 2.09 \mathrm{~g} \mathrm{~m}^{-2}\right)$ and in the mudflats $(4.06 \pm$ $1.79)$ than in the forest $(1.20 \pm 0.38)$. Seine nets caught fewer individuals $\left(0.95 \pm 0.17\right.$ fish $\left.\mathrm{m}^{-2}\right)$ and species $\left(0.03 \pm 0.01\right.$ species $\left.\mathrm{m}^{-2}\right)$, and lower biomass $\left(1.15 \pm 0.21 \mathrm{~g} \mathrm{~m}^{-2}\right)$ than pop nets (see above) in mudflats. Differences in the fish assemblage structure among zones suggest that overall fish biodiversity may increase in fragmented mangrove landscapes as relative amounts of edge to area increase, but this could detrimentally affect abundances and species richness of resident mangrove fishes.
\end{abstract}

KEY WORDS: Mangroves $\cdot$ Mudflat $\cdot$ Intertidal $\cdot$ Pop nets $\cdot$ Survey $\cdot$ Zonation

Resale or republication not permitted without written consent of the publisher

\section{INTRODUCTION}

Tropical mangroves are common in many estuaries and sheltered bays, and support rich assemblages of flora and fauna through the provision of shelter and stable substrata (Chapman \& Underwood 1995, Lee 1999, Kathiresan \& Bingham 2001). Many of the fish and invertebrates using mangroves support fisheries of considerable economic (Sasekumar et al. 1992) and social (de Boer et al. 2001) value, with fishery resources linked strongly to the 'health' of mangrove systems (Kathiresan \& Rajendran 2002). Temperate mangroves are poorly studied in comparison to tropical systems, and there is little understanding of the importance of temperate mangroves as a habitat for fish and invertebrates. 
The relative value of mangroves, compared with alternative (often adjacent) intertidal (e.g. mudflats, seagrass) and subtidal (e.g. coral reefs) habitats, to fish and invertebrates is well studied in the tropics (Blaber et al. 1989, Nagelkerken et al. 2000, Mumby et al. 2004), and better studied for juvenile than adult life stages (Robertson \& Duke 1987). Mangroves are generally thought to be more important to juvenile fishes than sparsely vegetated mudflats or intertidal seagrasses. This idea is based largely on correlative data (Nagelkerken et al. 2000, Hindell \& Jenkins 2004), although recent experimental and review studies suggest that mangrove structure minimises predation and maximises food availability (Laegdsgaard \& Johnson 2001, Sheridan \& Hays 2003). Conversely, Sheridan \& Hays (2003) found that nekton densities were sometimes lower in mangroves compared with adjacent habitats. Only 2 studies have compared fish use of mangroves with unvegetated mudflats in temperate regions. The results were highly variable in time and space (Clynick \& Chapman 2002, Hindell \& Jenkins 2004), but there was often little difference in response variables (e.g. fish abundance) between the 2 habitats.

Comparisons of fish use among habitats provide gross estimates of habitat usage, but in anticipation of the need for a more process-based approach to attributing values of importance to mangroves as fisheries habitat (Sheridan \& Hays 2003), and in recognition of the application of landscape-scale approaches to assessing fish-habitat relationships (Robbins \& Bell 1994, Bell et al. 2001), a better understanding of spatially explicit patterns of fish use within habitats (among microhabitats) must be gained. Mangroves have generally been treated as a single habitat unit, the value of which has been inferred from samples taken at 1 stratum (or zone), usually along the seaward edge (Hindell \& Jenkins 2004), but fish and invertebrate assemblages may vary strongly with distance into mangrove forests. Fish abundances and biomass may be greater at 'inland' mangrove positions (Ronnback et al. 1999), with juvenile fish and prawns moving considerable distances into mangrove forests (Vance et al. 1996), depending on topography and current patterns (Vance et al. 2002). Conversely, assemblages of epibenthic nekton may be more abundant and diverse along the edge than inner forest regions of mangroves (Vance et al. 1996, Meager et al. 2003). Understanding how assemblages of fish differ between the edge and interior of mangroves, and how these patterns differ from adjacent habitats will have applications in improving sampling of mangroves per se and in understanding the consequences of habitat fragmentation.

Bottomless pop-up nets (sensu Connolly 1994; also called bottomless lift nets, Rozas 1992), hereafter referred to as pop nets, have been effective in sam- pling nekton from intertidal habitats such as salt marshes and seagrass with high levels of structure, but have not been used in mangroves. Pop nets are advantageous over alternative gears (e.g. throw, seine, drop, flume and block nets) because sampling efficiency is not reduced by dense vegetation, their use is not restricted to areas along navigable channels and they can be set-off remotely (Kneib 1991, Rozas 1992, Connolly 1994). A potential drawback in using pop nets is that there is often significant disturbance of the sampling area by trampling and digging-in of net structure. This disturbance may attract or disperse fish and invertebrates, thereby confounding measures of association for a particular habitat type, but no study has attempted to address this issue experimentally.

The present study consists of 2 parts. First, we assessed artefacts associated with setting pop nets (pop net artefact experiment) by investigating whether the disturbance of setting pop nets influenced local assemblages of fish in habitats of widely different structural complexity (intertidal seagrass versus intertidal unvegetated sand). Second, we compared fish assemblages among mangrove zones (pop net survey of fish in intertidal habitats) (1) to quantify densities of fish using mangrove forest $(\approx 20$ to $30 \mathrm{~m}$ landward of the seaward margin of the mangroves), mangrove edge (seaward margin of mangroves) and sparsely vegetated mudflat; (2) to compare pop net catches to those of traditional gears such as beach seine nets; and (3) to examine whether inundation regimes influence assemblages of nekton using intertidal habitats.

\section{MATERIALS AND METHODS}

Study regions. The pop net artefact experiment was performed in Port Phillip (144 38' 57.594' E, 3807' 39.884" S, see Hindell et al. 2000), a large (1950 km²), circular, semi-enclosed tidal embayment (Black et al. 1993), joined with the ocean of Bass Strait through a narrow rocky entrance. Tides in Port Phillip are semidiurnal with a range of less than $1 \mathrm{~m}$; currents are generally weak (Black et al. 1993) and there is little thermal or salinity stratification (Longmore et al. 1990). A study region was chosen in Port Phillip because it has large areas of intertidal seagrass Zostera muelleri Irmisch ex Ascherson 1867 amongst which are dispersed patches of unvegetated sand. We have excellent baseline data on fish-habitat associations over the last 10 yr in Port Phillip (Jenkins \& Black 1994, Jenkins \& Wheatley 1998, Jenkins \& Hamer 2001) and the study area was accessible in all weather conditions, enabling us to maximise the number of sampling dates.

The pop net survey of fish in intertidal habitats was performed in Western Port $\left(145^{\circ} 11^{\prime} 27.180^{\prime \prime} \mathrm{E}, 38^{\circ} 21^{\prime}\right.$ 
17.349" S, see Hindell \& Jenkins 2004), a tidally dominated system (semi-diurnal with a range of $2.3 \mathrm{~m}$ ) with approximately $90 \mathrm{~km}^{2}$ of intertidal mudflat, $15 \mathrm{~km}^{2}$ of which is covered by a single species of mangrove, the grey mangrove Avicennia marina (Forskaal) Vierhapper 1967. Individual trees here are smaller $(<3 \mathrm{~m}$ in height) than in the tropics, where this species may exceed $10 \mathrm{~m}$ (Harty 1997), and the stands of mangroves are largely restricted to protected regions of the bay where the substratum is muddy sand. The study region in Western Port was chosen because it has large stands of mangrove, the substratum is firm enough to enable nets to be set by foot and we have a good understanding of the local fish assemblages (Robertson 1980, Edgar \& Shaw 1995a). The intertidal can be separated into 3 habitat zones: (1) mangrove forest $(\approx 20$ to $30 \mathrm{~m}$ landward of the seaward edge of the mangroves); (2) mangrove edge (seaward edge of the mangrove forest); and (3) intertidal mudflat (an area of the intertidal without mangroves at the terrestrial-marine confluence). Intertidal elevation gradually decreases from the mangrove forest to the edge, but the cycles and extent of tidal inundation were similar between the mudflat and the mangrove edge.

Study design. Pop net artefact experiment: The pop net artefact experiment assessed whether the disturbance of setting nets influenced fish assemblages that used habitats of different structural complexity (sea- grass, unvegetated sand). The design of the pop nets was based on that of Connolly (1994) and enabled nets to be constructed in situ. Each net had $5 \times 5 \mathrm{~m}$ buoyant and weighted frames made from $20 \mathrm{~mm}$ PVC pipe (Fig. 1A). Silicone sealant was used to seal air inside the buoyant frame; steel rods ( $10 \mathrm{~mm}$ diameter by $4 \mathrm{~m}$ ) were placed inside the weighted frame. The frames were attached to the top (buoyant frame) and bottom (weighted frame) of a net ( $20 \mathrm{~m}$ long $\times 1.2 \mathrm{~m}$ high with $1 \mathrm{~mm}$ mesh and a zip at 1 end to allow the net to be formed into an enclosure) by sliding $5 \mathrm{~m}$ lengths of frame into 'sleeves'. The $5 \mathrm{~m}$ frame components were joined via $20 \mathrm{~mm}$ PVC 'elbows'.

On each of 5 different occasions, a single replicate of each of 3 net treatments (pop net + channel, channel only, unmanipulated) was set up in seagrass and unvegetated sand at low tide. The pop net + channel treatment consisted of a $5 \times 5 \mathrm{~m}$ channel $(5 \mathrm{~cm}$ deep and $10 \mathrm{~cm}$ wide) within which a pop net (including frames) was placed. The buoyant frame was attached to the weighted frame with two $20 \mathrm{~mm}$ plastic hose clamps (combined with a cable tie) placed at intervals along each side (Fig. 1B) and the net was held in the channel with steel pegs. The channel treatment was a $5 \times 5 \mathrm{~m}$ channel of the same dimensions as above. The unmanipulated treatment was an area without any channel or pop net. Different plots of each habitat were used on successive occasions (i.e. nets were packed up

A) Plan view

B) Lateral view

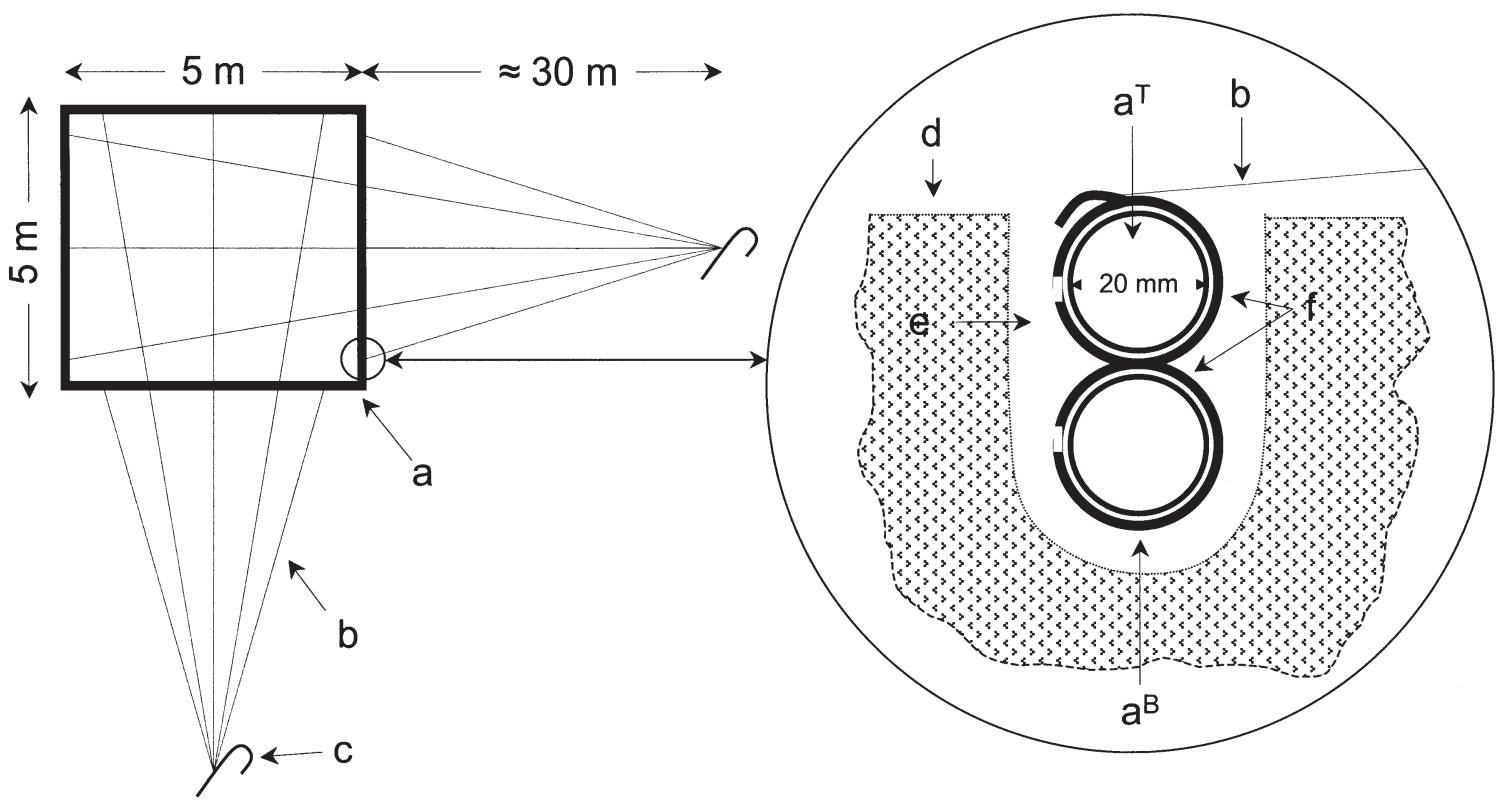

Fig. 1. Design of pop nets showing (A) view from directly above and (B) a cross section through the net frames seated within a channel. a: net frame $\left({ }^{\mathrm{T}}\right.$ : top-buoyant; ${ }^{\mathrm{B}}$ : bottom-weighted); b: remote-release lines; $\mathrm{c}$ : steel pegs, d: surface of substratum, e: channel, f: plastic clips to hold top and bottom frame together before release. Note that figure is not drawn to scale 
and treatments reapplied to previously unmanipulated plots).

Fish using the treatments in each habitat were collected with a small beach seine net $(10 \mathrm{~m}$ long $\times 2 \mathrm{~m}$ high with $1 \mathrm{~mm}$ mesh) at high tide. These nets have been used extensively to sample small and juvenile fishes in seagrass and unvegetated sand habitats (Connolly 1994, Jenkins et al. 1997b). The beach seine net was set around 1 corner of the treatment plot and hauled across to the opposite corner.

Pop net survey of fish in intertidal habitats: Pop nets were used to quantitatively sample fish in 3 mangrove zones (forest, edge, mudflat) on 7 different occasions. A different plot of each habitat was selected on each occasion ( $\mathrm{n}=7$ ), so that nets were not repeatedly sampling the same area. Pop nets were set in the substratum according to the methods above (for pop net + channel). Care was taken to ensure there were no gaps through which fish could escape between the substratum and the weighted frame. A release mechanism, consisting of a $20 \mathrm{~kg}$ monofilament line joined to plastic hose clamps at 3 positions along each side of the net (Fig. 1A), was attached to each pop net so that they could be set off remotely. For each pair of opposing sides, lines were run to a single point $30 \mathrm{~m}$ away, which was marked with a buoy so that it could be found at high tide (Fig. 1A). The nets were built in situ so that they could be set around mangrove trees and other structures. At high tide, a person waded quietly to each buoy and retrieved the steel peg with the lines attached. The monofilament lines were then simultaneously pulled to release the buoyant frame, which rose to the surface within 1 to $2 \mathrm{~s}$. Nets were monitored to prevent bird predation. When the tide had receded, trapped fish were collected by hand.

A beach seine net (as in the pop net artefact experiment) was used to sample fish at high tide from mudflats so that we could compare this method with pop nets. The pneumatophore zone and mangrove forest could not be sampled with the seine net because of the high levels of structure. Setting and retrieving this seine net is well described (Jenkins et al. 1997a,b). Briefly, 1 of the $10 \mathrm{~m}$ ropes attached to the side of the seine net was set in a straight line, the net was then set at approximately $60^{\circ}$ to the rope and the final rope was set at approximately $60^{\circ}$ to the net in the form of an equilateral triangle. The net was then hauled into a bin by 2 people, sampling an area of approximately $75 \mathrm{~m}^{2}$. Water depth at the time of setting pop and seine nets was recorded so that we could assess whether samples varied with the degree of tidal inundation.

In both the experimental and survey parts of our study, fish were identified to species and their length (from the snout to the caudal peduncle, SL; mm) was measured. In the pop net survey, the weight (g) of each fish was also recorded. Fish that could not be identified in the field were anaesthetised, preserved in ethanol and returned to the laboratory, where they were identified to species (Gomon et al. 1994), and their SL and weight measured. All work was carried out between October 2003 and January 2004.

Statistical analysis. Univariate data: All data were checked for normality and homogeneity of variances. Data that failed to meet these assumptions were transformed $\left(\log _{10} x+1\right)$ and reassessed.

For the pop net artefact experiment, differences in fish abundance, species richness and abundance of gobiids (the most common family caught) among net treatments and between habitats were compared using 2-factor analyses of variance (ANOVAs). Net treatment and habitat were treated as fixed factors, and sampling occasions provided the replication ( $\mathrm{n}=$ 5). Differences among levels of fixed factors were assessed with a posteriori planned comparisons (Quinn \& Keough 2002). Power analyses were used to assess our confidence in detecting a difference among net treatments if one actually existed (Quinn \& Keough 2002), and were calculated based on an effect size of $100 \%$ (e.g. a doubling of fish numbers) using $\mathrm{G}^{*}$ Power (available at www.psycho.uni-duesseldorf.de/aap/ projects/gpower) (Erdfelder et al. 1996). This effect size was within the range of variability recorded in previous studies that quantified fish abundances in seagrass and unvegetated sand at our study region (Jenkins et al. 1997b, Hindell et al. 2000).

For the pop net survey, fish abundance, biomass and species richness were adjusted by the area of habitat sampled; pop and seine nets sampled areas of 25 and $75 \mathrm{~m}^{2}$, respectively. Differences in fish abundance, biomass and species richness among zone by gear combinations (i.e. pop net-forest, pop net-edge, pop netmudflat, seine net-mudflat) were compared with 1-factor ANOVAs. The net by habitat combination was treated as a fixed factor and sampling occasions provided the replication $(n=7)$. Planned comparisons were used to assess whether variables (1) sampled with pop nets differed among zones, and (2) sampled only from mudflats differed between seine and pop nets. The relationship among variables (fish abundance, biomass and species richness) and water depth was analysed with regression analyses for zones and gear types separately. Probability values from these analyses were adjusted using a Bonferroni procedure (Quinn \& Keough 2002) to reduce the type-I error rate. All univariate analyses were performed with SYSTAT statistical software (Wilkinson et al. 1992).

Multivariate data: The similarity in the assemblage structure of fish among (1) net treatments and habitats 
(pop net artefact experiment), and (2) habitats and gear types (pop net survey) were analysed with nonmetric multidimensional scaling (nMDS) based on Bray-Curtis dissimilarity measures (Clarke \& Warwick 2001). Data were 4 th root-transformed to reduce the influence of numerically dominant species. A priori null hypotheses were tested statistically with analyses of similarity (ANOSIM), and similarity percentages (SIMPER) were used to calculate the relative contributions to differences by particular species. Where multiple pair-wise tests were performed, p-values were adjusted using Bonferroni corrections to reduce the experimental type-I error rate (Quinn \& Keough 2002). All multivariate analyses were performed with Primer version 5.0 (Clarke \& Warwick 2001).

\section{RESULTS}

\section{Pop net artefacts}

In assessing whether setting pop nets altered assemblages of fish associated with habitats of different structural complexity (seagrass and unvegetated sand), 464 fish from 14 species (9 families) were collected (Table 1). Assemblages of fish varied weakly between habitats (ANOSIM: global $\mathrm{R}=0.165$, $\mathrm{p}=0.044 ;$ Fig. 2), but not among net treatments (ANOSIM: global $\mathrm{R}=-0.155, \mathrm{p}=0.990$; Fig. 2). SIMPER showed that Favonigobius lateralis (36\%), Rhombosolea tapirina (14\%), Heteroclinus perspicilatus $(11 \%)$ and Nesogobius sp. 1 (9\%) contributed to $70 \%$ of the difference in assemblage structure between habitats.

There was little difference in total fish abundance, species richness and gobiid abundance among net treatments or between habitats (Table 2, Fig. 3). Only species richness differed significantly between habitats, with more species in seagrass than unvegetated sand (Fig. 3). Importantly, with respect to assessing whether setting pop nets in habitats of different structural complexity influenced fish samples, the interaction terms between pop net treatment and habitat were highly non-significant $(p>0.586)$ for all 3 variables. The statistical power to detect differences of $100 \%$ was adequate (Table 3). There was at least an $80 \%$ likelihood of detecting a significant $(p<0.05)$ change of $100 \%$ in abundances of fish (effect size) associated with the pop net + channel or channel only treatments compared to unmanipulated plots in seagrass and unvegetated sand. The power of the statistical analyses to assess whether species richness and abundances of gobiids varied between treatments was lower (40 to $50 \%$ ) in unvegetated sand (Table 3), but $97 \%$ for species richness in seagrass.

\section{Pop net survey of fish in intertidal habitats}

The pop nets collected 15 species of fish from 9 families (Table 4). Benthic fishes such as gobiids (6 species) dominated ( $42 \%$ of all fish caught), but semi-pelagic species (e.g. Atherinasoma microstoma, Sillaginodes punctata, Aldrichetta forsteri, Arripis trutta and Arripis truttacea) were also sampled. Many of the fishes, particularly the gobiids, were adult/subadult stages, but juvenile stages of $S$. punctata, Rhombosolea tapirina, A. forsteri and the arripids were also collected (Table 4).

The assemblage structure of fish differed strongly among habitats (ANOSIM: global $\mathrm{R}=0.603, \mathrm{p}=0.001$; Fig. 4). Fish assemblages collected with the pop nets in the forest were different from those along the edge (ANOSIM: global $\mathrm{R}=0.357, \mathrm{p}=0.006$; Fig. 4A) and mudflat (ANOSIM: global $\mathrm{R}=0.987, \mathrm{p}=0.001$; Fig. 4A). SIMPER showed that the same 5 species (Pseudogobius olorum, Atherinasoma microstoma, Mugilogobius paludis, Tetractenos glaber and Favonigobius lateralis) explained at least $88 \%$ of the differences between forests and the other zones (edge and mudflat), $50 \%$ of which was due to $P$. olorum. The strong difference in assemblage structure between edge and mudflat (ANOSIM: global $\mathrm{R}=0.415, \mathrm{p}=$

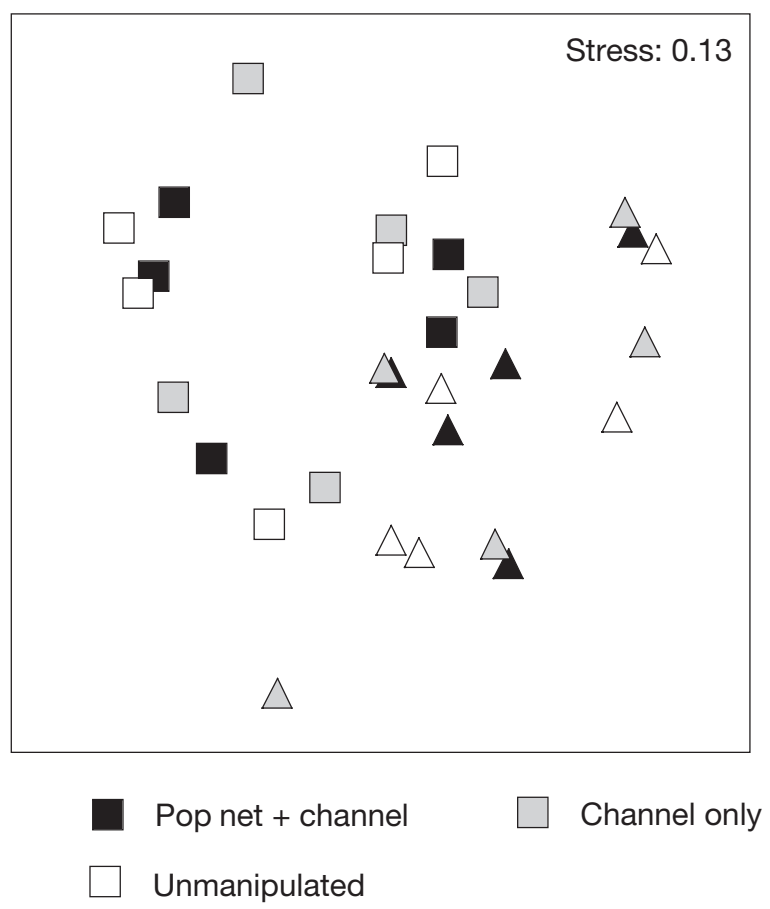

Fig. 2. Multidimensional scaling plot, based on Bray-Curtis dissimilarity measures, comparing assemblages of fish among treatments of the pop net artefact experiment (pop net + channel, channel only, unmanipulated) for each level of structural complexity (seagrass [squares] versus unvegetated sand [triangles]). $\mathrm{n}_{\text {total }}=30$ 


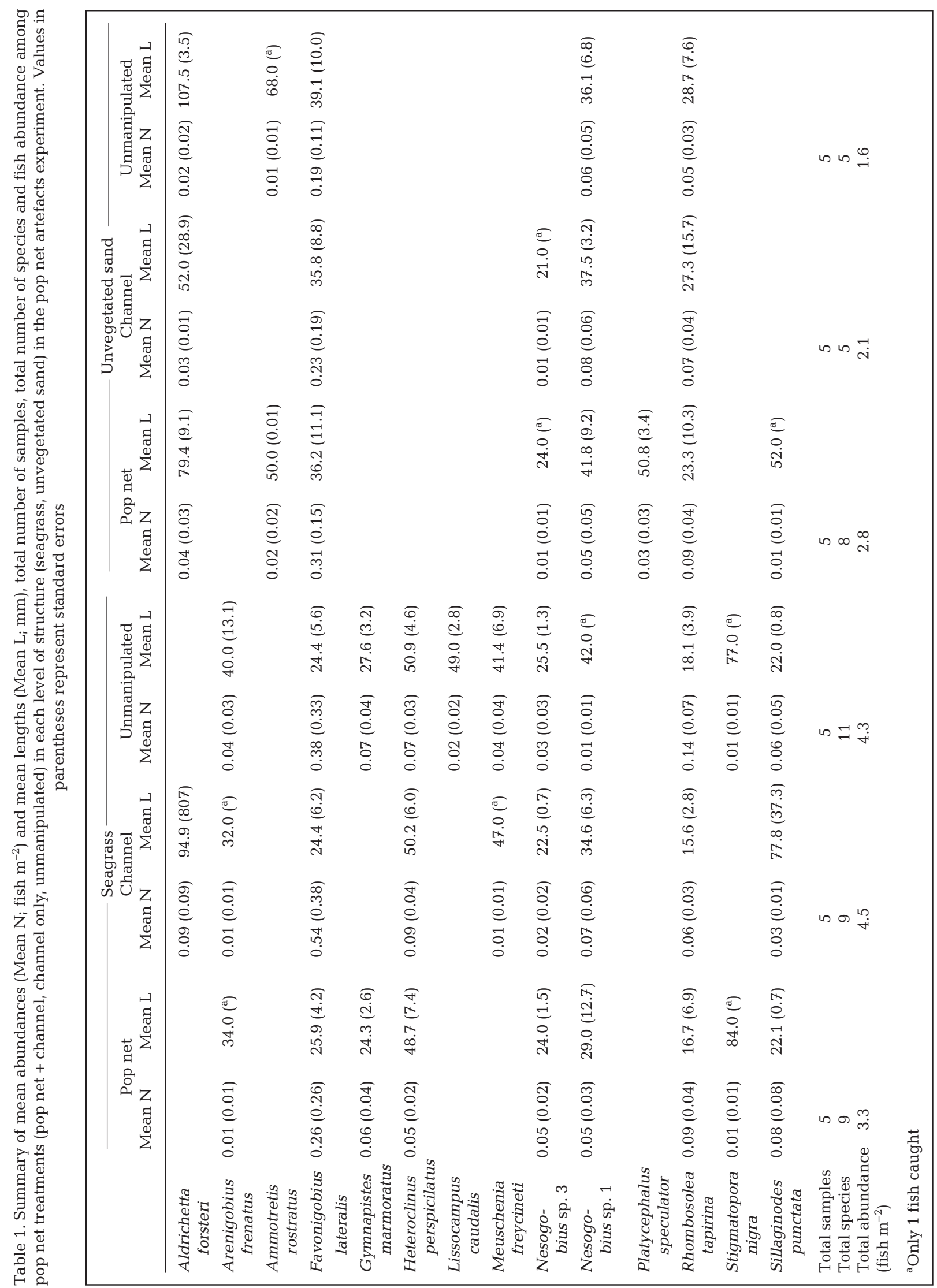


Table 2. Summary of 2-factor ANOVA comparing total fish abundance, species richness and gobiid abundance among net treatments (pop net + channel, channel only, unmanipulated) and between levels of structure (seagrass, unvegetated sand). Statistically significant $(p<0.05)$ results shown in bold

\begin{tabular}{|c|c|c|c|c|c|c|c|}
\hline \multirow[t]{2}{*}{ Source } & \multirow[t]{2}{*}{$\mathrm{df}$} & \multicolumn{2}{|c|}{$\begin{array}{c}\text { Total fish } \\
\text { abundance }\end{array}$} & \multicolumn{2}{|c|}{$\begin{array}{l}\text { Species } \\
\text { richness }\end{array}$} & \multicolumn{2}{|c|}{$\begin{array}{c}\text { Gobiid } \\
\text { abundance }\end{array}$} \\
\hline & & $F$ & $\mathrm{p}$ & $F$ & $\mathrm{p}$ & $F$ & $\mathrm{p}$ \\
\hline Net treatment (N) & 2 & 0.050 & 0.951 & 0.016 & 0.985 & 0.039 & 0.962 \\
\hline Structure (S) & 1 & 3.374 & 0.079 & 7.585 & 0.011 & 0.619 & 0.439 \\
\hline $\mathrm{N} \times \mathrm{S}$ & 2 & 0.547 & 0.586 & 0.275 & 0.762 & 0.170 & 0.845 \\
\hline Error & 24 & & & & & & \\
\hline
\end{tabular}

$\mathrm{R}=0.669, \mathrm{p}=0.001 ;$ Fig. 4B); F. lateralis, T. glaber and A. frenatus were more common in pop than seine nets (Table 4) and contributed more than $75 \%$ to the differences between gears.

Fish abundances (ANOVA: $\mathrm{df}=3,24$, $F=9.790, \mathrm{p}<0.001)$ and species richness (ANOVA: df $=3,24, F=21.823, \mathrm{p}<$ $0.001)$ differed significantly among zones, but fish biomass did not (ANOVA: $\mathrm{df}=3,24, F=1.757, \mathrm{p}=0.185$; Fig. 5). Fish abundances were greater in forests (Planned Comparison [PC]: $\mathrm{df}=$ $1,24, F=16.231, \mathrm{p}<0.001)$ and along the edge (PC: $\mathrm{df}=$ $1,24, F=6.835, \mathrm{p}=0.015$ ) than in mudflats, but not significantly different between edges and forest (PC: $\mathrm{df}=1,24$, $F=2.000, \mathrm{p}=0.170)$. There was no significant difference in fish abundance collected on mudflats between seine and pop nets (PC: $\mathrm{df}=1,24, F=0.477, \mathrm{p}=0.496)$. Species richness was greater along edges than in forests (PC: $\mathrm{df}=$ $1,24, F=8.425, \mathrm{p}=0.008$ ) or mudflats (PC: $\mathrm{df}=1,24$, $F=20.805, \mathrm{p}<0.001)$, and differed little between forests and mudflats (PC: $\mathrm{df}=1,24, F=3.743, \mathrm{p}=0.110$ ), although the species composition was markedly different (see above). Significantly more species were sampled with the pop than the seine nets (PC: $d f=1,24, F=$ 21.871, $\mathrm{p}=0.003$ ).

Fish abundance, species richness and biomass collected with the pop nets varied weakly with water depth, regardless of the habitat. Once the significance levels were adjusted (Bonferroni procedure), however, depth did not explain a significant amount of variability for any of the variables $(p>0.016)$.

\section{DISCUSSION}

\section{Utility of pop nets for sampling fishes}

Accurately quantifying abundances of fish in habitats with high levels of structure can be exceedingly difficult. Seine and trawl nets are largely limited to habitats with little 'rigid' structure such as seagrass and unvegetated sand. Fyke and gill nets, fish traps and underwater video are useful in sampling fish in habitats with high levels of physical structure, such as rocky/coral reefs and mangroves, but do not accurately measure density, only relative estimates of occurrence. Pop nets are advantageous over these gears, in that they can be used to sample habitats with high levels of rigid structure and provide measures of density. Unfortunately, however, pop nets are effort-intensive to set up, and a consequence of this effort is that the area immediately adjacent to the net is greatly disturbed by, for example, human trampling and digging the net into
0.001) was driven by 4 of the above species; however, M. paludis was replaced by Arenigobius frenatus. Assemblages of fish collected over mudflats differed strongly between seine and pop nets (ANOSIM: global 
Table 3. Summary of statistical power analyses of changes of $100 \%$ (Effect size) in the variables (Total fish abundance, Species richness, Gobiid abundance) in the manipulated (pop net + channel, channel only) versus unmanipulated plots in each level of structure (seagrass, unvegetated sand). Mean values of variables (fish $25 \mathrm{~m}^{-2}$ ) have been $\log _{10}(x+1)$-transformed. Actual percent differences between unmanipulated and manipulated treatments given in parentheses. SD: standard deviation. All analyses were performed at $F_{2,12}=3.885$. $\lambda$ : non-centrality parameter

\begin{tabular}{|c|c|c|c|c|c|c|c|}
\hline Variable & Unmanipulated & $\begin{array}{c}\text { Treatment } \\
\text { Channel }\end{array}$ & Pop net & $\pm \mathrm{SD}$ & $\begin{array}{c}\text { Effect size } \\
100 \%\end{array}$ & $\lambda$ & Power $(\%)$ \\
\hline \multicolumn{8}{|l|}{ Unvegetated sand } \\
\hline Total fish abundance & 0.84 & $0.82(2)$ & $1.03(23)$ & 0.40 & 1.65 & 14.125 & 85 \\
\hline Species richness & 0.34 & $0.33(3)$ & $0.42(24)$ & 0.23 & 0.67 & 6.840 & 53 \\
\hline Gobiid abundance & 0.68 & $0.60(12)$ & $0.79(16)$ & 0.56 & 1.36 & 4.926 & 48 \\
\hline \multicolumn{8}{|l|}{ Seagrass } \\
\hline Total fish abundance & 1.21 & $1.19(2)$ & $1.09(10)$ & 0.40 & 2.42 & 30.361 & 99 \\
\hline Species richness & 0.61 & $0.62(2)$ & $0.56(8)$ & 0.23 & 1.21 & 22.329 & 97 \\
\hline Gobiid abundance & 0.80 & $0.93(16)$ & $0.83(4)$ & 0.56 & 1.59 & 6.808 & 53 \\
\hline
\end{tabular}

the mud. This raises 2 questions, neither of which have been previously considered. (1) Does the disturbance influence estimates of assemblage structure by, for example, attracting some species and/or dispersing others? (2) Are the effects of disturbance consistent between habitats of widely differing structural complexity? The second question is pertinent given that the aim of many studies is to compare fish assemblages using alternative habitats, often with very different structural attributes. In our study, the disturbance of setting pop nets changed neither the assemblage structure nor univariate measures of abundance (e.g. species richness or total numbers), regardless of the structural complexity of the habitat. Furthermore, these patterns were not simply a reflection of type II errors, that is concluding 'no effect' when there actually was one. Power analyses showed that we often had power in excess of $80 \%$ to detect changes in fish abundance among pop net treatments. Our results that no disturbance effect is observed when setting pop nets enable subsequent differences (or lack thereof) among habitats to be interpreted as habitat-specific processes rather than sampling artefacts.

Small $(<20 \mathrm{~m})$ beach seines are commonly used to collect fish in soft sediments and provide reliable estimates of abundance for many nektonic taxa (Connolly 1994, Jenkins et al. 1997b). The use of pop nets is also an efficient method of collecting small and juvenile fishes, and there is some evidence that these nets are actually better at sampling intertidal fishes than seine nets (Connolly 1994, Rozas \& Minello 1997). The pop nets in our study collected more species, greater biomass and larger numbers of fish than seine nets. The 'assessment of artefacts' component of our study showed that this difference was not simply due to sampling bias. As in the work of Connolly (1994), the pop nets used in our study were highly effective at catching smaller sedentary species, particularly gobiids. Previ- ous sampling in the same region with fyke and gill nets, however, collected few small fishes (Hindell \& Jenkins 2004). Furthermore, in our study, transient species such as Arripis truttacea and Tetractenos glaber, which move over scales of 100 s to 1000 s of metres, were also collected, helping to dispel concerns that pop nets are restricted to sampling only small $(<5$ $\mathrm{cm}$ ), relatively sedentary (that move over scales of $10 \mathrm{~s}$ of metres) species.

\section{Assemblages of fish associated with temperate mangroves}

Temperate mangroves are thought to have fewer species and lower abundances of fish than tropical systems (Clynick \& Chapman 2002, Hindell \& Jenkins 2004), possibly as a function of latitudinal trends in productivity (Saenger \& Snedaker 1993, Alongi et al. 2000). Accurate estimates of density are rare in tropi$\mathrm{cal} /$ subtropical systems and completely absent in temperate mangroves (until our study). In our study, total densities of fish in the forest (13.9 fish $\mathrm{m}^{-2}$ ) exceeded those of the tropical system studied in Barletta et al.

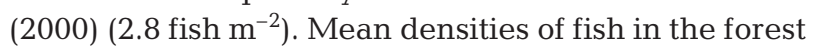
(2.0 fish $\mathrm{m}^{-2}$ ) and along the edges $\left(1.4 \mathrm{fish}^{-2}\right)$ in our study were also greater than those measured in the tropics by Vance et al. (1996) (1.0 fish $\mathrm{m}^{-2}$ in forest and 0.3 fish $\mathrm{m}^{-2}$ along mangrove edge), but less than Ronnback et al. (1999) (5.1 fish $\mathrm{m}^{-2}$ ). Notwithstanding potential differences in the gears used, total species richness was considerably lower in our study (15 species overall and 8 species inside mangroves) compared with Vance et al. (1996) along the creek/mangrove interface (26 species) and Ronnback et al. (1999) (37 species), but similar to Barletta et al. (2000) (14 species). Our study represents the first quantitative estimates of fish density and species richness in temperate 


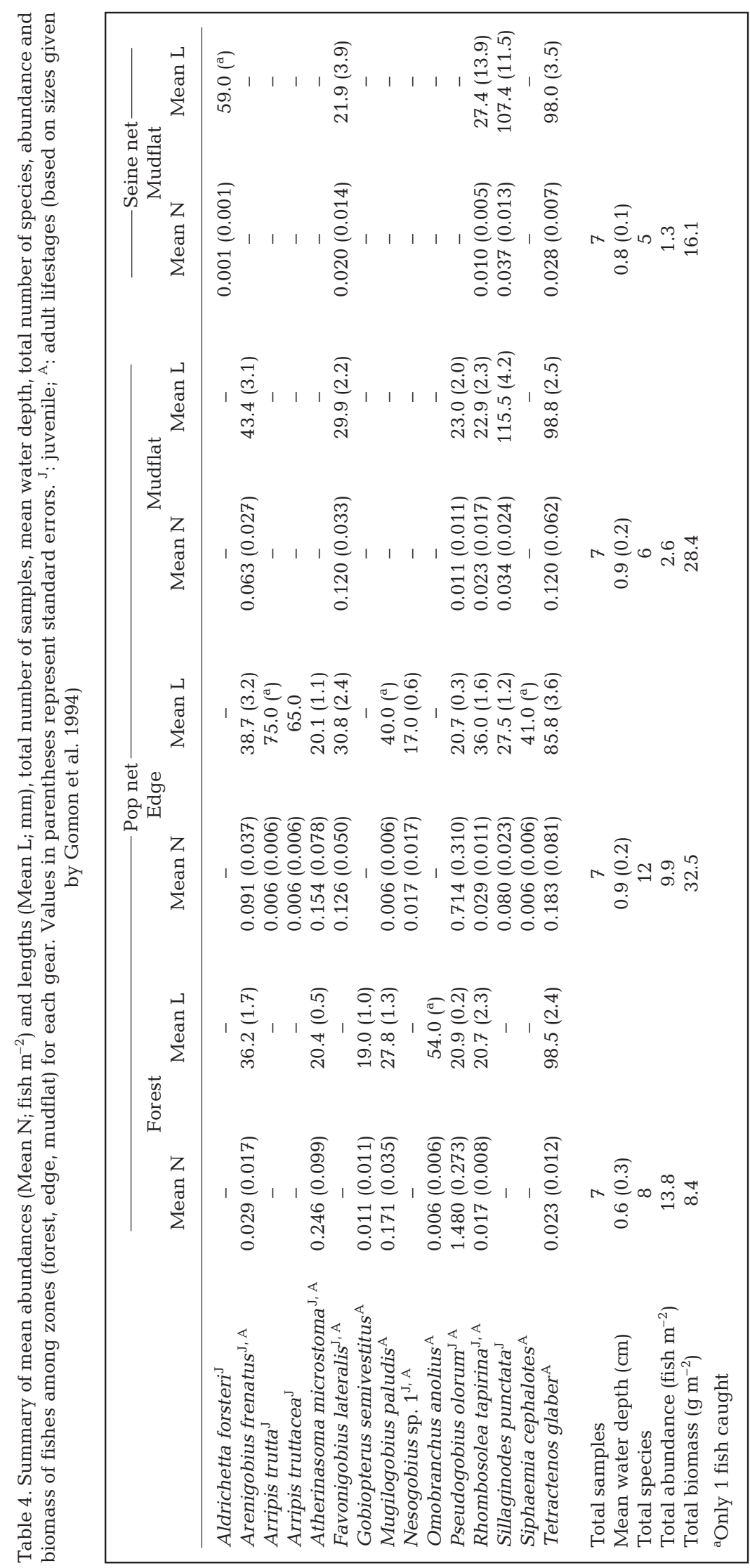

mangroves. While our study is consistent with previous work showing relatively low species richness in temperate systems (Clynick \& Chapman 2002, Hindell \& Jenkins 2004), fish densities are comparable to those measured in tropical and subtropical mangroves.

\section{Variability in assemblages of fish using mangroves versus mudflats}

Fish abundances and species richness in mangroves are often greater than those in adjacent mudflats (Kathiresan \& Bingham 2001), and this pattern is thought to reflect greater provision of food and/or protection from predation via structure provided by mangroves (Laegdsgaard \& Johnson 2001). The degree to which temperate mangroves support richer fish assemblages than adjacent mudflats strongly depends on location (Hindell \& Jenkins 2004), but at most locations, abundances and species richness are greatest in mangroves. Interpreting these patterns from previous tropical studies may have been difficult because fish assemblages that used mangroves were often compared with those that used alternative habitats at different depths or proximity to the shore (e.g. Nagelkerken et al. 2000). In our study, however, large gaps (100s of metres) between mangrove stands enabled us to sample mudflats with almost identical regimes of tidal inundation and proximity to the shoreline. Although we collected a similar number of species between habitats, the taxa and fish abundances from mangroves were very different to those of mudflats. Small taxa dominated by gobiids occurred almost exclusively inside mangrove forests, whereas larger mobile species were common on mudflats. Fish abundances were $>4$ times greater in mangroves than mudflats, while biomass showed the reverse pattern. Given the refuge role of mangroves, it is possible that small fishes may be confined to mangroves in our system by larger predatory fishes such as arripids, which are common along habitat edges and over unvegetated habitat (Robertson 1982, 

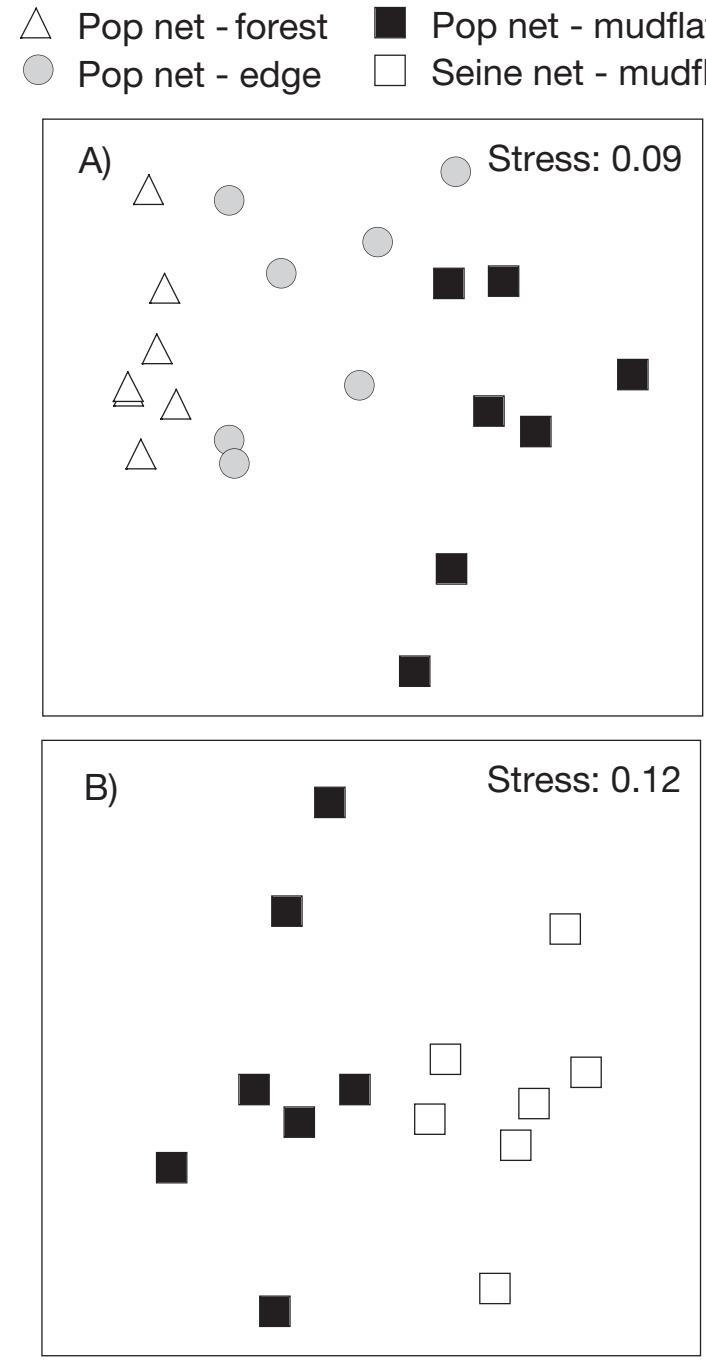

Fig. 4. Multidimensional scaling plots, based on Bray-Curtis dissimilarity measures, comparing assemblages of fish (A) among zones (forest, edge and mudflat) for pop nets only and (B) between seine and pop nets in mudflat only. $\mathrm{n}_{\text {total }}=28$

Hindell et al. 2000). The larger fishes that use mudflats, such as Sillaginodes punctata, may be too large for these predatory species to consume. Alternatively, mangroves may have lower abundances of infauna than adjacent habitats (Alongi \& Sasekumar 1992). Many of the infaunal/epifaunal taxa important in the diets of fish use unvegetated mudflats (Edgar \& Shaw 1995b), so a greater biomass of fish (and larger size of fishes) using mudflats may also reflect energy budgets and local variability in the availability of prey.

The most abundant species collected from mudflats (Sillaginodes punctata, Favonigobius lateralis and Tetractenos glaber) in our study were consistently sampled from mudflats and seagrass beds throughout Western Port by Edgar \& Shaw (1995a) and Robertson
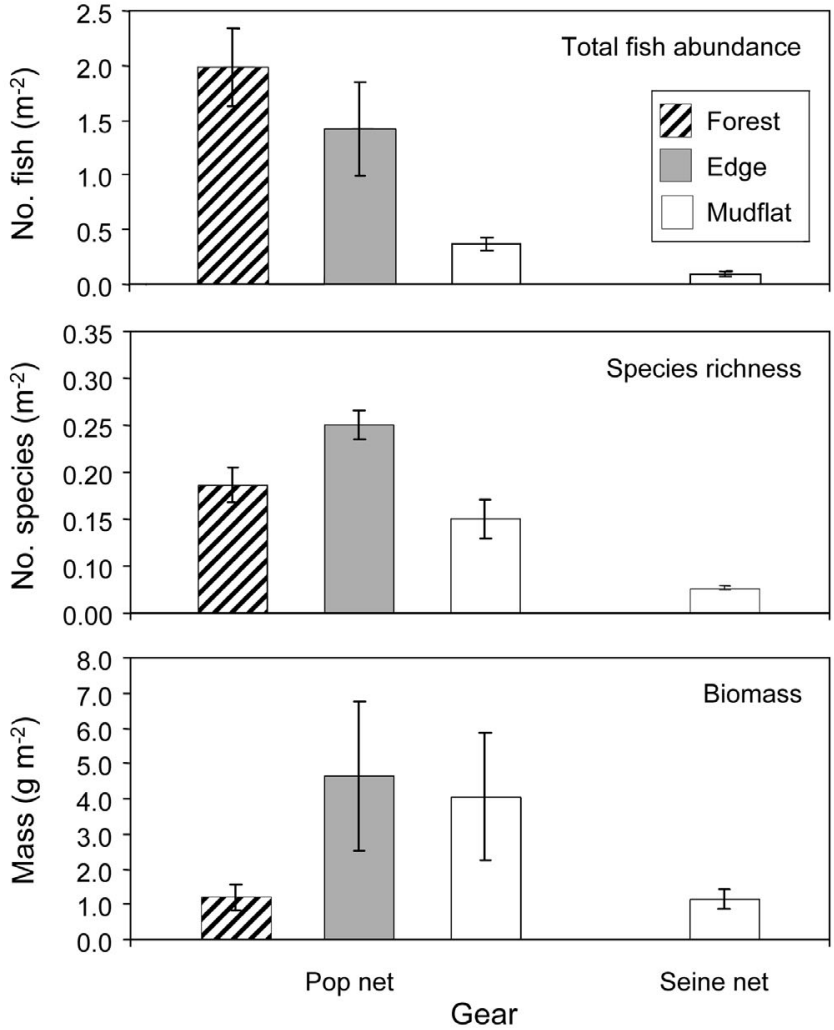

Fig. 5. Mean $( \pm \mathrm{SE})$ total fish abundance, species richness and biomass $\left(\mathrm{m}^{-2}\right)$ among zones (forest, edge, mudflat) collected with pop and seine nets. $n_{\text {total }}=28$

(1980). One of the most abundant species we collected in mangroves (Pseudogobius olorum) was common on mudflats adjacent to stands of mangroves in other regions of Western Port (Edgar \& Shaw 1995a). The other abundant mangrove-associated fish (Atherinasoma microstoma) was not taken from unvegetated mudflats in either our study or that by Robertson (1980), although in Robertson's study, this species was common in seagrass. Rhombosolea tapirina was common across all habitats in our study, but previously only occurred over mudflats. The most conspicuous species sampled primarily from mangrove forests in our study (Mugilogobius paludis) was not recorded previously, and may be one of the few truly resident species in our temperate mangrove system.

The intertidal nature of mangroves may preclude their use by fish at low tide unless they can remain in deeper channels with residual water, take refuge in burrows, or have physiological adaptations enabling them to remain out of water (Barletta et al. 2000, 2003). Fishes using forests in our study were dominated by small (<30 mm) gobiids, some of which (e.g. Mugilogobius paludis) are rarely caught outside mangroves (Robertson 1980, Edgar \& Shaw 1995a). The man- 
groves in our study have few (if any) deeper channels with residual water at low tide, so 'resident' species must have physiological adaptations that enable them to cope with periods of emergence and/or seek refuge in burrows, buried in the mud or hidden in epiphytes attached to pneumatophores (Barletta et al. 2000). If fish were seeking refuge in crab burrows or were able to withstand extended periods of emergence, we would not have expected them to aggregate in the last remaining water at the lowest point of the pop net (the point from which they were collected). It is possible that some 'resident' species may follow the falling tide to the seaward edge of the mangroves, at which stage they seek refuge within epiphytes and in smaller water depressions, to minimise emergence times and desiccation. This is purely speculative, however, and further work is needed to better understand the fine-scale patterns (over metres) of movement of intertidal fishes with tidal flooding regimes.

\section{Zonation of fish assemblages in mangroves}

Stands of mangroves are generally viewed as a single habitat and sampling is commonly restricted to the edges of forests, often along the seaward edge of navigable channels. There is growing realisation, however, that fish assemblages vary greatly among micro-habitats within stands of mangroves. Ronnback et al. (1999) and Meager et al. (2003) have shown strong patterns of zonation for fish and invertebrates in tropical mangroves. Ronnback et al. (1999) found large differences in fish assemblages between microhabitats (pneumatophore versus prop roots) within mangrove forests, and richer assemblages inside the forest than along the edge. Conversely, Vance et al. (1996) reported greater abundances and more species of fish along the mangrove fringe than at sites inside the forest. Meager et al. (2003) also observed greater numbers of epibenthic crustaceans at the mangrove edge than inner forest sites, and this pattern was not driven by microhabitat differences (vegetated versus cleared) between locations. Our results show that fish assemblages along mangrove edges are as different from those inside the mangrove forest as those in adjacent mudflats. Assemblages inside the forest were dominated by small taxa, particularly gobiids, whereas those along the edge consisted of more species and greater mean size. Fish abundance differed little between forest and edge, but species richness and biomass were lower in forest than along the edge. Recent work by Vance et al. (2002) shows that differences in faunal abundances among regions within mangrove forests largely depend on local topography and water currents. In our study, water depth within a zone was a poor predictor of fish abundance, species richness, or biomass among sampling occasions. More likely, broad differences in physical structure, and the effects of this structure on productivity and faunal interactions (e.g. predation), are most important in shaping patterns of zonation of fish within mangrove forests.

The greatest species richness, biomass and abundances (the latter 2 in association with mudflats and forests, respectively) of fish along the edges of mangroves in our study is consistent with work in tidal marsh systems showing significant edge effects. Invertebrate and vertebrate taxa may vary strongly at the edge of salt marshes, with species richness and abundance of nekton both increasing and decreasing, respectively, with distance into salt marshes (Peterson \& Turner 1994, Minello et al. 2003). There can be strong links between infauna and nekton near the marsh edge when decreases in infaunal densities close to the marsh edge coincide with increased abundances of nekton predators (Whaley \& Minello 2002), and strong positive relationships between nekton abundances and amounts of intertidal edge (Webb \& Kneib 2002). While there can be a lot of variation in numbers of species and densities of nekton between locations within a marsh (Thomas \& Connolly 2001, Osgood et al. 2003), the patterns depend on whether the unvegetated or vegetated edge of the marsh is compared with the interior vegetated regions (Minello et al. 2003).

Coastal habitats such as mangroves are increasingly under threat from urbanisation, pollution and climate change (Alongi 2002). A consequence of these processes can be the fragmentation of existing habitat units, with concomitant increases in perimeter to area ratios as patch size decreases. There is a need to understand how the value of habitat changes with fragmentation (Forman \& Godron 1986), and how assemblages respond to changes in landscape structure (McNeill \& Fairweather 1993). Our results showed strong differences in fish assemblages between the edge and interior of mangroves. The fragmentation of mangroves (and subsequent increases in the relative amounts of edge to interior) is likely to increase the overall biodiversity of fishes using this habitat in our study region, but may detrimentally influence abundances of species resident within the mangrove forest.

Acknowledgements. We gratefully acknowledge funding from the Fisheries Research and Development Corporation (FRDC 2001/036) and Fisheries Victoria. Thanks to P. Fraser, A. Plummer and S. Heislers for assistance in the field and in the laboratory. Earlier versions of this manuscript were improved by colleagues and comments from 3 anonymous reviewers. This work was performed using the facilities at Marine and Freshwater Systems, PIRVic and the Queenscliff Marine Station. 


\section{LITERATURE CITED}

Alongi DM (2002) Present state and future of the world's mangrove forests. Environ Conserv 29:331-349

Alongi DM, Sasekumar A (1992) Benthic communities. In: Robertson AI, Alongi DM (eds) Tropical mangrove ecosystems. American Geophysical Union, Washington, DC, p 137-172

Alongi DM, Tirendi F, Clough B (2000) Below-ground decomposition of organic matter in forests of the mangroves Rhizophora stylosa and Avicennia marina along the arid coast of Western Australia. Aquat Bot 68:97-122

Barletta M, Saint-Paul U, Barletta-Bergan A, Werner E, Schories D (2000) Spatial and temporal distribution of Myrophis punctatus (Ophichthidae) and associated fish fauna in a northern Brazilian intertidal mangrove forest. Hydrobiologia 426:65-74

Barletta M, Barletta-Bergan A, Saint-Paul U, Hubold G (2003) Seasonal changes in density, biomass, and diversity of estuarine fishes in tidal mangrove creeks of the lower Caete Estuary (northern Brazilian coast, east Amazon). Mar Ecol Prog Ser 256:217-228

Bell SS, Brooks RA, Robbins BD, Fonseca MS, Hall MO (2001) Faunal response to fragmentation in seagrass habitats: implications for seagrass conservation. Biol Conserv 100: 115-123

Blaber SJM, Brewer DT, Salini JP (1989) Species composition and biomasses of fishes in different habitats of a tropical northern Australian estuary: their occurrence in the adjoining sea and estuarine dependence. Estuar Coast Shelf Sci 29:509-531

Black K, Hatton D, Rosenberg M (1993) Locally and externally-driven dynamics of a large semi-enclosed bay in southern Australia. J Coast Res 9(2):509-538

Chapman M, Underwood A (1995) Mangrove forests. In: Underwood A, Chapman M (eds) Coastal marine ecology of temperate Australia. University of New South Wales Press, Sydney, p 187-204

Clarke KR, Warwick RM (2001) Changes in marine communities: an approach to statistical analysis and interpretation. 2nd edn. Primer-E, Plymouth

Clynick B, Chapman M (2002) Assemblages of small fish in patchy mangrove forests in Sydney Harbour. Mar Freshw Res 53:669-677

Connolly RM (1994) A comparison of fish assemblages from seagrass and unvegetated areas of a southern Australian estuary. Aust J Mar Freshw Res 45:1033-1044

de Boer W, van Schie A, Jocene D, Mabote A, Guissamulo A (2001) The impact of an artisinal fishery on a tropical intertidal benthic fish community. Environ Biol Fish 61:213-229

Edgar GJ, Shaw C (1995a) The production and trophic ecology of shallow-water fish assemblages in southern Australia. I. Species richness, size-structure and production of fishes in Western Port, Victoria. J Exp Mar Biol Ecol 194: 53-81

Edgar GJ, Shaw C (1995b) The production and trophic ecology of shallow-water fish assemblages in southern Australia. II. Diets of fishes and trophic relationships between fishes and benthos at Western Port, Victoria. J Exp Mar Biol Ecol 194:83-106

Erdfelder E, Faul F, Buchner A (1996) GPOWER: a general power analysis program. Behav Res Meth 28:1-11

Forman R, Godron M (1986) Landscape ecology. Wiley, New York

Gomon MF, Glover JCM, Kuiter RH (1994) The fishes of Australia's South Coast. State Print, Adelaide

Harty C (1997) Mangroves in NSW and Victoria: forests of the tidal zone in temperate Australia. Vista Publications, Melbourne

Hindell J, Jenkins G (2004) Spatial and temporal variability in the assemblage structure of fishes associated with mangroves (Avicennia marina) and intertidal mudflats in temperate Australian embayments. Mar Biol 144:385-396

Hindell JS, Jenkins GP, Keough MJ (2000) Variability in abundances of fishes associated with seagrass habitats in relation to diets of predatory fishes. Mar Biol 136:725-737

Jenkins GP, Black KP (1994) Temporal variability in settlement of a coastal fish (Sillaginodes punctata) determined by low-frequency hydrodynamics. Limnol Oceanogr 39(7): 1744-1754

Jenkins G, Hamer P (2001) Spatial variation in the use of seagrass and un-vegetated habitats by post-settlement King George whiting (Percoidei: Sillaginidae) in relation to meiofaunal distribution and macrophyte structure. Mar Ecol Prog Ser 224:219-229

Jenkins GP, Wheatley MJ (1998) The influence of habitat structure on nearshore fish assemblages in a southern Australian embayment: comparison of shallow seagrass, reef algal, and unvegetated habitats, with emphasis on their importance to recruitment. J Exp Mar Biol Ecol 221:147-172

Jenkins GP, Black KP, Wheatley MJ, Hatton DN (1997a) Temporal and spatial variability in recruitment of a temperate, seagrass-associated fish is largely determined by physical processes in the pre- and post-settlement phases. Mar Ecol Prog Ser 148:23-35

Jenkins GP, May HMA, Wheatley MJ, Holloway MG (1997b) Comparison of fish assemblages associated with seagrass and adjacent unvegetated habitats of Port Phillip Bay and Corner Inlet, Victoria, Australia, with emphasis on commercial species. Estuar Coast Shelf Sci 44:569-588

Kathiresan K, Bingham B (2001) Biology of mangroves and mangrove ecosystems. Adv Mar Biol 40:84-136

Kathiresan K, Rajendran N (2002) Fishery resources and economic gain in three mangrove areas on the south-east coast of India. Fish Manage Ecol 9:277-283

Kneib RT (1991) Flume weir for quantitative collection of nekton from vegetated intertidal habitats. Mar Ecol Prog Ser 75:29-38

Laegdsgaard P, Johnson C (2001) Why do juvenile fish utilise mangrove habitats? J Exp Mar Biol Ecol 257:229-253

Lee S (1999) Tropical mangrove ecology: physical and biotic factors influencing ecosystem structure and function. Aust J Ecol 24:355-366

Longmore AR, Cowdell RA, Gibbs CF (1990) Monitoring Port Phillip Bay water quality 1985-86. Scientific Report Series 89/003, Environmental Protection Authority Victoria, Melbourne

McNeill SE, Fairweather PG (1993) Single large or several small marine reserves? An experimental approach with seagrass fauna. J Biogeogr 20:429-440

Meager J, Vance D, Williamson I, Loneragan N (2003) Microhabitat distribution of juvenile Penaeus merguiensis de Man and other epibenthic crustaceans within a mangrove forest in subtropical Australia. J Exp Mar Biol Ecol 294: $127-144$

Minello TJ, Able KW, Weinstein MP, Hays CG (2003) Salt marshes as nurseries for nekton: testing hypotheses on density, growth and survival through meta-analysis. Mar Ecol Prog Ser 246:39-59

Mumby P, Edwards A, Arias-Gonzalez J, Lindeman K and 8 others (2004) Mangroves enhance the biomass of coral reef fish communities in the Caribbean. Nature 427: 533-536

Nagelkerken I, Van der Velde G, Gorissen M, Meijer G, Van't 
Hof T, Den Hartog C (2000) Importance of mangroves, seagrass beds and the shallow coral reef as a nursery for important coral reef fishes, using a visual census technique. Estuar Coast Shelf Sci 51:31-44

Osgood D, Yozzo D, Chambers R, Jacobson D, Hoffman T, Wnek J (2003) Tidal hydrology and habitat utilisation by resident nekton in Phragmites and non-Phragmites marshes. Estuaries 26:522-533

Peterson GW, Turner RE (1994) The value of salt marsh edge vs interior as a habitat for fish and decapod crustaceans in a Louisiana tidal marsh. Estuaries 17:235-262

Quinn G, Keough M (2002) Experimental design and data analysis for biologists. Cambridge University Press, Cambridge

Robbins BD, Bell SS (1994) Seagrass landscapes: a terrestrial approach to the marine subtidal environment. Trends Ecol Evol Biol 9(8):301-304

Robertson AI (1980) The structure and organisation of an eelgrass fish fauna. Oecologia 47:76-82

Robertson AI (1982) Population dynamics and feeding ecology of juvenile Australian salmon (Arripis trutta) in Western Port, Victoria. Aust J Mar Freshw Res 33: 369-375

Robertson AI, Duke NC (1987) Mangroves as nursery sites: comparisons of the abundance and species composition of fish and crustaceans in mangroves and other nearshore habitats in tropical Australia. Mar Biol 96:193-205

Ronnback P, Troell M, Kautsky N, Primavera JH (1999) Distribution pattern of shrimps and fish among Avicennia and Rhizophora microhabitats in the Pagbilao mangroves, Philippines. Estuar Coast Shelf Sci 48:223-234

Rozas LP (1992) Bottomless lift net for quantitatively sampling nekton on intertidal marshes. Mar Ecol Prog Ser 89: 287-292

Editorial responsibility: Otto Kinne (Editor-in-Chief), Oldendorf/Luhe, Germany
Rozas LP, Minello TJ (1997) Estimating densities of small fishes and decapod crustaceans in shallow estuarine habitats: a review of sampling design with focus on gear selection. Estuaries 20:199-213

Saenger P, Snedaker S (1993) Pantropical trends in mangrove above-ground biomass and annual litterfall. Oecologia 96: 293-299

Sasekumar A, Chong VC, Leh MU, D'Cruz R (1992) Mangroves as a habitat for fish and prawns. Hydrobiologia 247:195-207

Sheridan P, Hays C (2003) Are mangroves nursery habitat for transient fishes and decapods? Wetlands 23:449-458

Thomas BE, Connolly RM (2001) Fish use of subtropical saltmarshes in Queensland, Australia: relationships with vegetation, water depth and distance onto the marsh. Mar Ecol Prog Ser 209:275-288

Vance DJ, Haywood MDE, Heales DS, Kenyon RA, Loneragan NR, Pendrey RC (1996) How far do prawns and fish move into mangroves? Distribution of juvenile banana prawns Penaeus merguiensis and fish in a tropical mangrove forest in northern Australia. Mar Ecol Prog Ser 131: 115-124

Vance D, Haywood M, Heales D, Kenyon R, Loneragan N, Pendrey R (2002) Distribution of juvenile penaeid prawns in mangrove forests in a tropical Australian estuary, with particular reference to Penaeus merguiensis. Mar Ecol Prog Ser 228:165-177

Webb S, Kneib R (2002) Abundance and distribution of juvenile white shrimp Litopenaeus setiferus within a tidal marsh landscape. Mar Ecol Prog Ser 232:213-223

Whaley S, Minello T (2002) The distribution of benthic infauna of a Texas salt march in relation to the marsh edge. Wetlands 22:753-766

Wilkinson L, Hill M, Vang E (1992) SYSTAT: statistics, version 5.2 edition. SYSTAT, Evanston, IL

Submitted: May 27, 2004; Accepted: September 14, 2004 Proofs received from author(s): March 17, 2005 